Journal of Contemporary Educational Research

Research Article

\title{
The Influence of the Pluralism of Chinese Language and Literature on the Tradition of Literary Criticism
}

\author{
Shijing Sun \\ Wuchang Branch of Harbin Radio and TV University, Harbin 150200, China
}

\begin{abstract}
The current problems facing literary criticism are not only the influence of the external environment, but also the understanding of the traditional Chinese culture from the perspective of "globalization" and "diversification" of literature. It is also a guide for related literary criticism. This paper first discusses the pluralism of literary criticism, gives an overview of literary criticism, analyzes the problems of literary criticism in Chinese literature in our country, and finally propoeses relevant suggestions for literary criticism under pluralism.
\end{abstract}

Keywords: Literary diversity; Tradition of literary valuation; Influence

Publication date: August, 2020

Publication online: 31 August, 2020

*Corresponding author: Shijing Sun, 1635833321@ qq.com

\section{Introduction}

Over the years, the economic development, cultural development and ideological liberalization of our society have mutually promoted each other. At present, all countries are prosperous due to the development trend of the global economy. In addition, daily economic and trade exchanges will inevitably promote the exchange and integration of cultural ideologies. China is an ancient civilization with a long history. Our predecessors and pioneers have left us a lot of wealth, and the most glorious is Chinese traditional culture. At present, Chinese culture is increasingly recognized by people with the further development of China's economy. In recent years, various development trends of Chinese literature have become stronger. However, the influence of the pluralism of Chinese literature on our literary criticism tradition is still under discussion and how to perfect the tradition of literary criticism is of great significance.

\section{Overview of pluralism and literary criticism}

At the end of the last century, there was a literary boom in the criticism of Chinese literature, but when many scholars used the term "pluralism" in literary criticism, they did not fully understand its meaning. The pluralism here does not mean political pluralism, economic pluralism and social pluralism. Some scholars have even included it into the diverse worldviews of various countries and regions, emphasizing that diversity is the end of literary criticism, exaggerating the status and role of literary criticism in the diversity of Chinese language and literature, and enlarging the function of pluralism. It leads to mistaken ideology and restricts the development of tradition of literary criticism.

\section{1 "Globalization" and Literary Criticism}

"Globalization" is a process taking place in the world today, but it is mainly an economic process that its meaning is mainly economic should not be arbitrarily expanded. The so-called "globalization" refers to a group of financial elites expanding their power worldwide, raising the price index of commodity and services, and transmitting capital from poor nonWestern countries to wealthy countries. This is basically in line with the reality of "globalization." The question that really matters to us is not how China participates in the "globalization" process, but the impact of economic "globalization" on the criticism of Chinese culture and literature when defining "globalization" in the economic field. This is a very complicated issue. So far, it seems that few people have conducted in-depth research on it, from which we can know that: Does the "globalization" of the economy necessarily mean that the cultures of 
other nations are transitioning to "globalization", or are already "globalized". In other words, can the cultures of other nations be "globalized"? It is not a responsible attitude to give simple affirmative or negative answer to these questions, but it is not the fundamental issue of cultural and literary research.

\section{2 "Pluralism" and literary criticism}

"Diversity" is also a concept that people talk about frequently. In addition to political and economic implications, the concept usually has cultural implications. American scholar Huntington's “clash of civilizations" theory was introduced into China decades ago, and it seems to be the main source of "pluralism" theory. However, there should be two different levels in terms of cultural "pluralism", no matter what the difference in practice between the "clash of civilizations" theory and the "diversity" theory is after careful inspection. The distinction between these two levels is very important for our research, and it is also necessary to carefully study the true state of "pluralism". Domestic cultural scholars tend to focus on "comfort" and "Western" when they talk about the "pluralism" of different races, but they tend to ignore the true differences between each ethnic culture. They only knew Saussure, while Western cultures such as Kant and Aristotle ignored the phenomena of Indian culture, African culture and South American culture. When conducting academic research, it is impossible to talk about "cultural diversity" because it only fixes the viewpoint in one field.

\section{3 "Pluralism" in Chinese literature and cultural criticism}

The "pluralism" in Chinese literature is mainly due to academic research, and especially the role of knowledge is diversifying with the collision of market economy and cultural exchanges and the formation of cultural diversity $^{[1]}$. The criticism of Chinese literature mainly focuses on novels, biographies, rural novels, crime novels and other fields. The field of fiction has expanded the scope of cultural criticism, and cultural development trend conforms to specific social value orientations. The literature criticism in expression of literature forms must be dealt with in an objective manner in the research process regardless of opposition or favor so that the most basic form of the story can be discovered.

\section{Problems of the pluralism of Chinese literature in the tradition of cultural criticism}

\subsection{The "rootless" situation in the field of Chinese literature}

The phenomenon of "rootlessness" in Chinese language and literature is mainly manifested in the blind adaptation to Western culture, the belief that everything is good in Western culture, and the "differentiation" deviation from original knowledge in general. The system and concept based on "Western" culture are implemented in some common forms. The phenomenon of "differentiation" was the most serious in the May 4th movement, and the criticism of Chinese literature was separated from the criticism of traditional literature. Blindly adapting to the West is the first model to understand Marx's literary criticism theory in the original works of Marxism, while the other is the introduction of many Western literary classics. Their vocabulary and terminology are rooted in our country's literature and art. The commentary tradition has lost some discourse systems.

\subsection{The conflict and integration between Chinese and Western literature and culture}

When Western culture flooded in, the cultural criticism of Chinese literature was contrary to the theory of traditional literary criticism. The phenomenon of westernization became extremely serious, and the literary criticism of western countries became the standard and mode of Chinese experience. As the time went by, we gradually discovered that "direct usage" is no longer suitable for the current development, and their theories cannot become the standard of Chinese literature and literature criticism, so we have regained the theory of traditional literary criticism. The traditions of this era are far from the times, and the development of Chinese literary criticism has also been delayed. This phenomenon is something we don't want to face, but we must face it. At present, Chinese literature criticism has not been supported by Western critical theories, nor can it be proved by its own characteristics and local liturature criticism.

\subsection{The alienation of Chinese literature and literature criticism in real life}

Chinese literary critics still rely on paper and words when constructing their theories and opinions. They did not associate literary criticism with real life, and believed that academics had nothing to do with life. Started from the founding of New China, the gap between Chinese and literary concepts, theory and reality has also been widening. Some literary works also originated in life, but their literary criticism has lost the basic 
foundation of life ${ }^{[2]}$. However, the psychological habits, continuity and aesthetics in real life are the source of thought in literature criticism. Only by paying close attention to the psychological habits and cognition in real life can we obtain better inspiration for criticism and avoid falling into the field of text circulation. The phenomenon of literary prototype is separated from life, and literary criticism loses the value of life.

\subsection{The "distance" of creation and dissemination of literary culture}

The culture created by ordinary literati belongs to elite culture, while the others belong to popular culture. In the trend of the times, elite cultures continue to collide, showing a trend of alienation. Among them, elite culture can be divided into mainstream culture and non-mainstream culture. China's literature criticism mainly focused on elite culture around 1970s. However, with the emergence of popular culture represented by local elite culture, the status of literary criticism was impinged. Especially after the reform and opening up, the commodity economy continued to develop, and then mass culture became the culture in mainstream, and the Chinese ideology shifted to the center of economic construction, leading to the loss and depreciation of cultural values. As a result, the elite culture created by writers was forgotten, and this culture became more and more "alienated."

\subsection{The anxiety faced by the "modernization" of Chinese literature}

After the reform and opening up, Chinese literature gradually turned to "modernization", and literature criticism was also increasing. The most intuitive expression of literature criticism is the Nobel Prize in Literature. However, our achievements are far less than those of the West in Nobel literature, so we are actively learning Western culture and are not optimistic about African and Indian culture., China's attitude towards culture has changed after the people of South America and Africa won the Nobel Prize in Literature, gradually agreeing to the principle of cultural "pluralism" and insisting on pluralism in literature criticism. Literature promoted the development of culture, encouraged by the wave of "modernization", but it still lost its most basic characteristics.

\section{Suggestions for literature criticism under the pluralism of Chinese language and literature}

In the new era, we need to reconsider cultural diversity and carefully study the problems and difficulties faced by literature criticism, cultural environment changes and reconstruction. If you don't understand the local and traditional culture, you cannot promote "diversity".

\subsection{Based on the analysis of Chinese local cultural context}

In order to solve the problem of the current situation of literature criticism in Chinese language and literature, it is necessary to directly face the current situation of Chinese literature, analyze the meaning of the necessary "diversity" under the current situation, and enhance the understanding of local and traditional culture. The development of culture is caused by certain political, economic and social factors, and is influenced by mainstream and non-mainstream culture in the cultural environment. In fact, we should not use European and American culture to describe our own local culture. We must analyze and understand our own cultural background, understand the historical tradition of Chinese culture, and the difference between elite culture and popular culture and non-mainstream culture.

\subsection{Understanding tradition}

Criticism of Chinese literature with multicultural backgrounds needs to recognize "tradition" in order to solve problems and get rid of difficulties. For example, the "preaching" tradition belongs to Confucian culture, but does the "preaching" tradition still exist after the May Fourth Movement or after the reform and opening up? As one of the theories of "traditional literary criticism" in China, "books are used to convey Taoism", and because of the great differences between European and American cultures, the composition of Chinese literary criticism should not only focus on inherited traditions, but should also show that there is It is necessary to pay attention to what is expressed. People's internal accumulation, ideology and behavior habits and other traditions. Therefore, it is necessary to recognize "tradition" and construct "Chinese literary criticism" in order to get rid of the predicament of Chinese literary criticism with multicultural background.

\subsection{Understanding the relationship between Chinese and Western culture, tradition and modern culture}

Western culture has a great influence on Chinese literature. In the current multicultural background, Chinese literature criticism still cannot escape the erosion of Western culture and the conflict between Chinese and Western cultures, traditional culture and modern culture $^{[3]}$. For this reason, literature criticism of modern 
Chinese literature must pay attention to this thread and recognize the differences between traditional culture and modern culture, as well as between Chinese and Western cultures. He has a deep understanding of China's excellent literary criticism style and decisively does not adopt Western templates. At the same time, they could not figure out the relationship between Chinese culture and Western culture, traditional culture and modern culture. Therefore, in this case, we need to form an understanding of our own culture, establish correct concepts, and understand the relationship between them dialectically.

\section{Conclusion}

The literary criticism of Chinese literature is facing challenges of various thoughts and forms, such as the "rootless" situation in the field of Chinese language and literature; the conflict and integration between Chinese and Western literature and culture; the alienation of Chinese literature and cultural criticism in real life, and the "far distance" of cultural creation and dissemination. These problems can be solved by understanding the tradition and the relationship between Chinese and Western culture and the relationship between tradition and modern culture to improve literary criticism.

\section{References}

[1] Cheng SB. Seeking Roots for Chinese Literary CriticismComment on "Multiculturalism and the New Tradition of Chinese Literary Criticism" [J]. China Book Review, 2015(10): 5153.

[2] Yan J. Multiculturalism and Chinese Literary Criticism[J]. Journal of Xiamen University (Philosophy and Social Sciences Edition), 2015(4): 61-67.

[3] Zhang LX. Introduce Western literary theory and advocate independent thinking [J]. Literature and Art Research, 2014 (3): 5-9. 